\title{
進行性筋ジストロフィ一症 $(\mathrm{PMD})$ 患者の \\ エネルギー所要量に関する研究
}

\section{—PMD 患者の基礎代謝について—}
臼谷三郎, 西山邦隆, 木田和幸, 山内登, 苅 谷 克 俊, 秋 元 義 巳*, 森 山明 夫* 弘前火学医学部公衆衛生学教室, *国立療養所岩木病院

\section{Studies on Energy Requirement of Patients with Progressive Muscular Distrophy}

On the Basal Metabolism of PMD Patients-

Saburo Usutani, Kunitaka Nishiyama, Kazuyuki Kida, Noboru Yamauchi, Katsutoshi Kariya, Yoshimi Akimoto* and Akio Moriyama*

Department of Public Health, Hirosaki

University School of Medicine; *Iwaki Byoin National Sanatorium, Aomori

On 35 patients with progressive muscular distrophy (PMD) and 20 control patients in a sanatorium, measurements were made of basal metabolism (BM), an indispensable element for calculating the energy requirement.

The results obtained were as follows:

1) There has been a report that PMD patients have BMR equal or superior to its standard values for the Japanese. However, the difference in body weight between the patients indicates invalidity of this report. As PMD patients with the same body weight as the standard person have lowered BMR compared with the standard, PMD patients should be considered to have essentially low BMR.

2) A statistically significant linear regression relationship is established between the ratio of the patient's body weight to its standard value and the ratio of the patient's BMR to its standard value for the Japanese. Therefore, a possibility was suggested of presuming BMR of the individual patient according to its body weight.

Jpn. J. Nutr., 42 (4) 247 254 (1984)

\section{は じめに}

筋ジストロフィー症 (PMD) 快, 遺伝的基盤のもとに発症し, 骨格筋の進行性変性, 退行性萎縮を主徵とす るミオパチー (myopathy) に属する疾患群の1つである。

本症については，先人らによって，これまで鋭意研究が進められてはきたが，その原因は依然として不明で あり，本態的治療法も確立されていない。したがって，患者の体力の保持と悪化防止が本症に対する医療の現 実であり，患者の生活管理に占める栄盖の意義は大きい。

しかし，特殊な病態をもち，肥満やるい瘦などさむざすな体型をもつPMD 患者の，栄養処方の基礎とな るべきェネルギー所要量の算定法については，これふで明らかにされていなかった。そこで，著者らは，これ

Key words : nutritional allowance, energy requirement, basal metabolism, progressive muscular distrophy, relative body weight ratio

栄養所要量, エネルギー所要量, 基礎代謝, 進行性筋ジストロフィー症, 肥瘦度 
に関する研究の一端として，エネルギー所要量を算定する際の基本的要素である基礎代謝（BM）を測定し， 新知見を得たので報告する。

\section{方法}

\section{1. 対象}

国立療養所，岩木病院に入院加療中で，かつ， BM が測定可能な PMD 患者 35 人（11〜 57歳の男子 32 人， 12〜27歳の女子 3 人)，少よびこれの対照となるべき一般入院患者 20 人（ 9 〜 74歳の男子 16 人，27〜 51 歳の女 子 4 人）の計 55 人である。

なお対照者は，骨折などによる整形外科的疾患および，小児喘息などで長期療養中の患者である。

\section{2. 期間と室内気候条件}

昭和58年11月 $6 〜 9$ 日の 4 日間に測定した。病院は，集中暖房が行われており，自記温湿度計で測定した期 間内の室内平均気温は $21.3 \sim 22.7^{\circ} \mathrm{C}$ ，湿度64～69\%であって， BM の測定にふさわしいほぼ快適な温熱条件 下にあった。

\section{3. 測定方法}

Douglas Bag 法で採気し，労研式大型呼気分析器で，型のごとく分析を行った。なお，尿中窒素の測定は 行わなかった。

\section{結果}

\section{PMD 患者の性, 年齢別基礎代謝}

日本人の年齢別 $\mathrm{BM}$ 基準值 ${ }^{1)}$ 結えだ $\mathrm{BM}$ の年跲曲線の図に, 測定值 (BMR : $\mathrm{kcal} / \mathrm{kg} /$ 日）をプロットしたのが図 1 であ る。

いま，基準値の土10\%以内を正常範囲， +10\%以上を元進，-10\%以下を低下とす ると，一般対照患者は正常範囲に分布する ものが多いのに比べて, PMD 患者群では, 低下例が多いことが目立ち，六進例はわず か 2 例にすぎなかった。

女子は，測定例数が少ないので断定はで

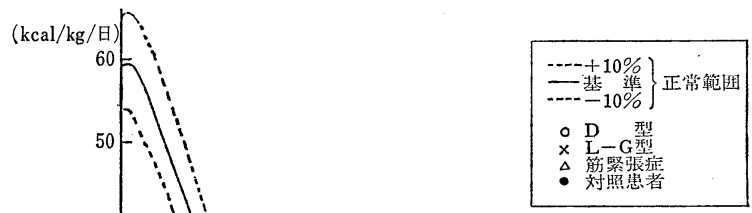

さないが，対象者 3 例の全てが低下例であった。このことは，男子と同じ傾向にあることを示唆している。

そこで，男子について，前記 3 域の度数分布をみると表 1 のごとくであり，PMD 患者群と対照患者群との 間に，分布上の差のある傾向をらかがい知ることができる。

また，PMD 患者群の中でも，比較的予後のよいLimb-girdle (L-G) 型では正常範囲例が多いのに対し て，これよりも予後の劣るDuchenne (D) 型では低下例が多いことなど，その病型によっても分布が異なる 傾向のあることを合わせ示しているよらに思われる。

次いで，各測定值 $(\mathrm{kcal} / \mathrm{kg} /$ 日) を患者の年齡に対応する $\mathrm{BM}$ 基準值で除して比率化 $(\% \mathrm{BMR}) し ， そ$ 
表 1 基礎代謝の水準別, 型別分布と基準值汇対する比率（男子）

(人)

\begin{tabular}{|c|c|c|c|c|c|c|c|c|}
\hline & & & & \multicolumn{4}{|c|}{$\begin{array}{llll}\mathrm{P} & \mathrm{M} & \mathrm{D} & \text { 患 者 群 }\end{array}$} & \multirow{2}{*}{ 対照患者群 } \\
\hline & & & & $\mathrm{D}$ 型 & L-G 型 & 筋緊張症 & 計 & \\
\hline 測 & \multirow{2}{*}{\multicolumn{2}{|c|}{ 定 零例 }} & 数 & 19 & \multirow[t]{2}{*}{10} & 3 & 32 & 16 \\
\hline 六 & & & 進 & $2(10.5) *$ & & 0 & $2(6.3)$ & $3(18.8)$ \\
\hline 正 & \multirow{2}{*}{\multicolumn{2}{|c|}{ 常範 }} & 团 & $6(31.6)$ & $7(70)$ & 0 & $13(40.6)$ & $8(50.0)$ \\
\hline 低 & & & 下 & $11(57.9)$ & $3(30)$ & $3(100)$ & $17(53.1)$ & $5(31.3)$ \\
\hline \multicolumn{4}{|c|}{ 基準值に対する比率 $\bar{x} \pm \mathrm{SD}$} & $89.9 \pm 21.2$ & $91.6 \pm 9.9$ & $71.1 \pm 11.4$ & $88.7 \pm 18.5$ & $98.5 \pm 12.6$ \\
\hline
\end{tabular}

*：（）内は\%

の平均值士標準偏差として表の下欄に示した。PMD 患者群のそれは，基準値の $88.7 \pm 18.5 \%$ となり，対照群 の98.5 土12.6\%とは有意差は認められなかった。

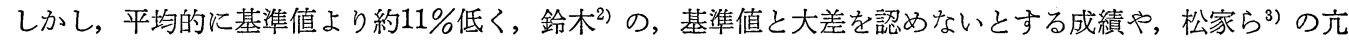
進するとする成績と明らかに異なる結果が得られた。

\section{PMD 患者の\% BMR と諸要因との関係}

前項で述べた，PMD 患者の BMR の水準に関する諸報告との矛盾を分析するために，次の検討を行った。

(1) 体重偏差值と\% BMR との関係

PMD 患者にみられる著しい体重の軽重差に，その原因があるのではないかと考兄，これについて検討する ことにした。

しかし，両値とも加齢変化が著しく，広範な年齢分布をする個人值を一括して論じるには，年齢因子を捨消 する必要がある。そこで, 患者值を日本人の栄養所要量に示された標準人の推計基準体重と BM 基準值でそ れぞれ除して比率化して，体重偏差值（\%）と\% BMR とし，両者の関係について検討した。

いま， $x$ 軸に体重偏差値を， $y$ 軸に\% BMR をとって，男子32例の值をプロットすると図 2 のようにな。 すなわち, 体重偏差值が減少するにつれて\% BMR が増加し, 統計的に有意な逆相関 $(r=-0.889, p<0.001)$ が得られ，前者に対する後者の回帰直線として，y=-0.974 $x+175.4$ が成立した。

上記の回帰直線は，次のことを意味している。

i） PMD 患者の体重が，基準体重に比べて“著しく軽い”場合の％BMR は著しく高く，“軽い”場合に

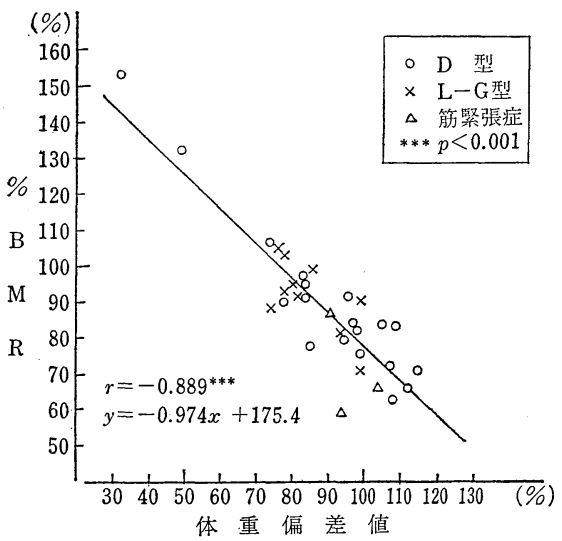

図 2 体重偏差值と\% BMR の相関

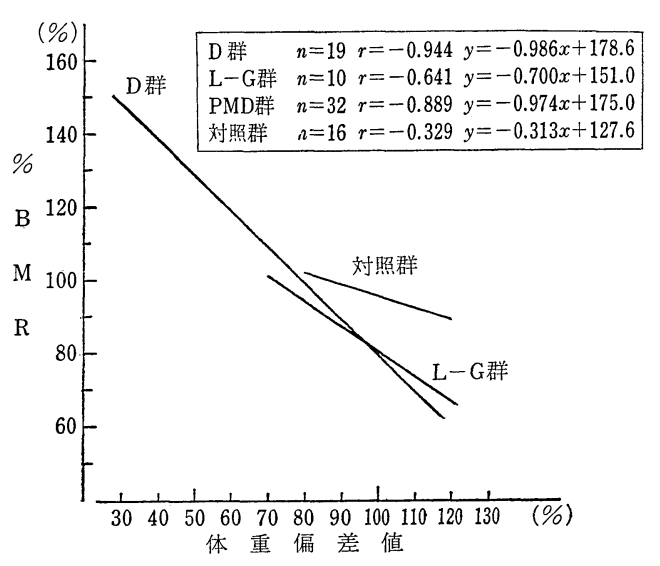

図 3 体重偏差值 $(x)$ 飞対する\% BMR $(y)$ の回帰直線 ( 37 ) 
表 2 肥瘦度等と\% $\mathrm{BMR}$ との関係（男子）

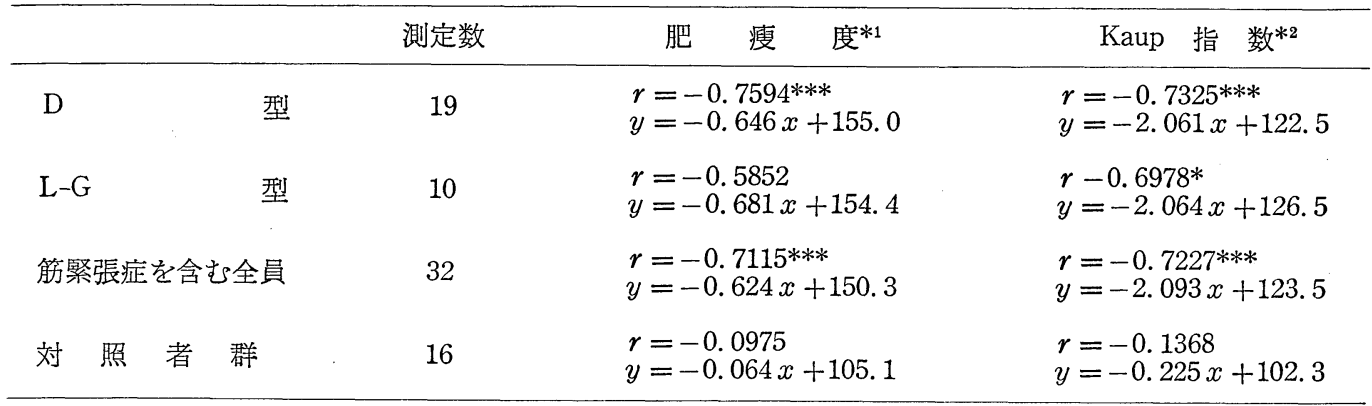

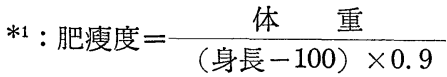

$* 2$ : Kaup 指数 $=$ 体重 $/$ 身長 $^{2}$

$*: p<0.05 \quad * * *: p<0.001$
}

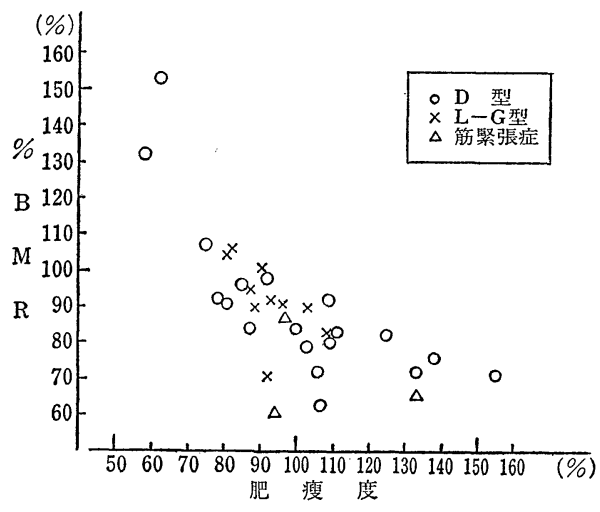

困 4 肥瘦度と\% BMR との関係

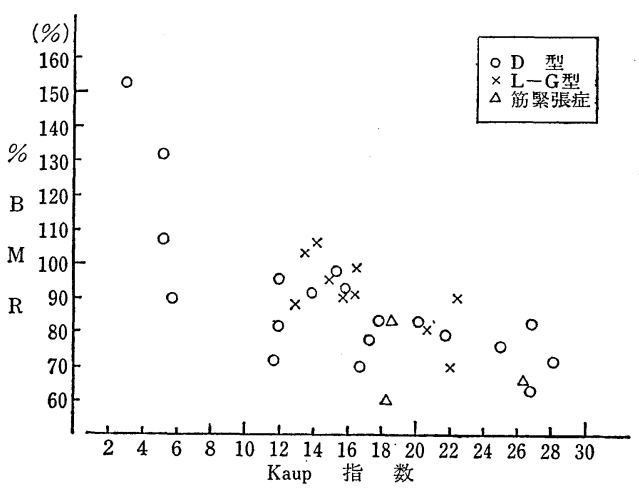

図 5 Kaup 指数 $\left(\mathrm{W} / \mathrm{H}^{2}\right)$ と\% BMR との関係

は正常域レベルにあるが，“同程度”からこれ以上になると，その体重増加に応じて\% BMR はますます 低下する。

ii）特に，PMD 患者の体重が“基準体重”にある場合には，その BM は標準人に示された基準値の78\% に低下する。

なお，上記の関係を，型別に，対照群と比較したのが図 3 である。D 型は L-G 型に比べて，回帰係数が 大きいが，これは両群の回帰直線が交差する体重偏差值 $97 \%$ 点を界して，その值が大きく，あるいは小さくな るにつれて，同じ体重偏差值でも両群間の\% BMR の差が增大することを示している。

(2) 肥瘦度等と\% BMR との関係

体重偏差值は，基準体重に対する軽重度であり，必ずしも患者個人の肥満やるい瘦の程度を示すものではな い。そこでこれとの関係を検討することにした。しかし，これの算出に必要な身長の測定值については， PMD 患者の場合，体の变形や関節の拘縮のために不正確な面があるが，一応，測定値を用いて，桂法によっ て算出した肥瘦度や，Kaup 指数と\% BMR との関係を示すと図 $4 ， 5$ のよらになる。

いずれも，両者間に有意の逆相関があることを表 2 は示している。図 4 のらち，特にD型についてみると， 
大雑把にいって, 肥瘦度の正常範囲90〜110\%のらち，標準体重の上限110\%以上では肥満が高度になるにつれ て\% BMR は減少するが，標準体重の下限 $90 \%$ 以下ではるい瘦が高度になるにつれて\% BMR が急增する傾 向を認めることができる。

また，図 5 でも同様の傾向をもつことが指摘できよう。

以上から，前項で述べた体重偏差値と\% BMR で示された関係には肥瘦度が大きく関与していることを知 ることができる。

(3.) 機能障害度等と\% BMR との関係

病勢の進展と\% BMR との関係をみるために, 図 6 では, 厚生省, 筋ジストロフィー研究班による 障害度分類によって，8段階に分類された Stage 別 の体重偏差值と\% BMR の平均值士標準偏差との 関係を, 図7 そは, 日常生活動作 (ADL) 障害度に 対する\% BMR のレベルの分布を示した。これらの 結果は, 結論からいって機能障害の程度と\% BMR との間には，明らかな相関関係が認められないこと を示している。

また，血清 $\mathrm{CPK}$ 活性値と\% BMR との関係を も検討した（図 8 ) が,これも同様の結果が得られ た。
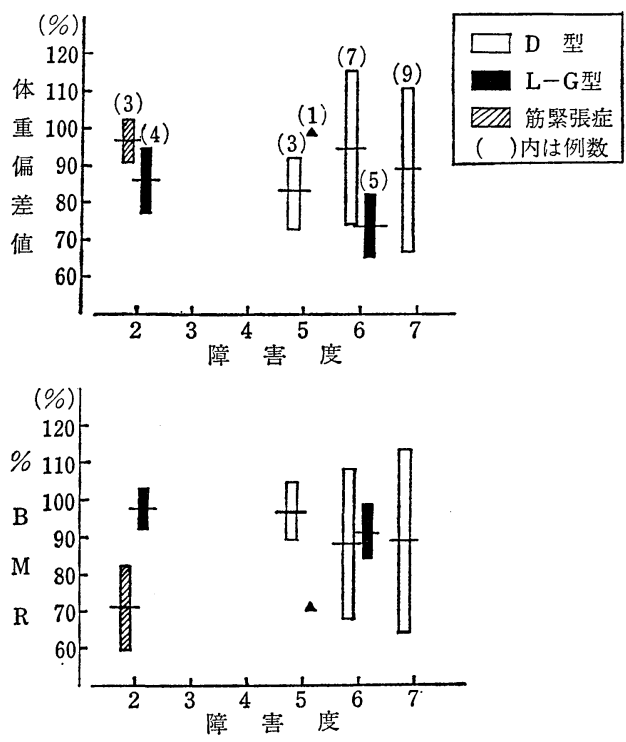

図 6 PMD 患者の障害度と体重偏差值,

\section{考察} \% BMRの推移

PMD の臨床像や臨床病理学的所見が 明 らかにされてきたのは，19世紀初頭からで ある。したがって，そのエネルギー代謝学 的知見も，これまでに十分集積されていて よさそうに思われるが，現実は必ずしもそ うではない。特に BM については, Du Bois ${ }^{4)}$ の名著“Basal metabolism in health and disease” はもとより, Duncan ${ }^{5)} や$

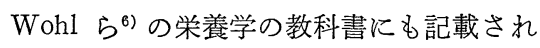
ていない。

また，我が国に和ける最近の PMD に関

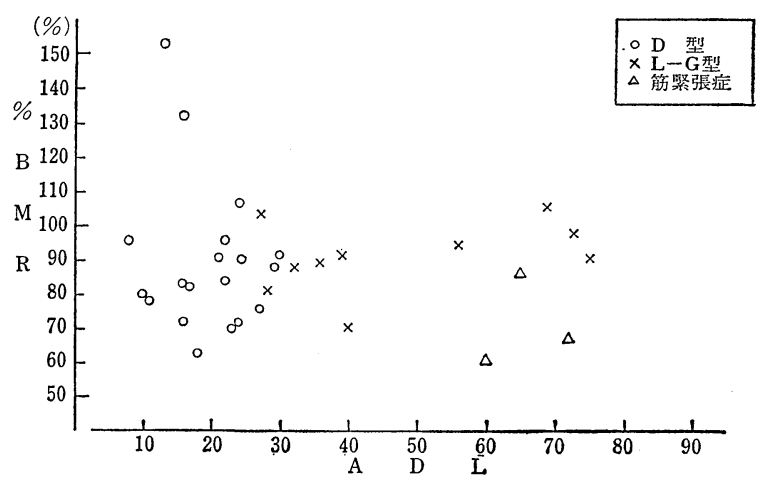

困 7 PMD 患者の ADL と\% BMR との関係 する著書7)8) や総説的論文 ${ }^{9)}$ においてる $\mathrm{BM}$ についてはふれられていない。これらのことは，PMD の研究は病因論的接近が主流であって，保健栄養学的 接近については, 必ずしも重視されてこなかったことを意味するのであろう。しかし，本症の原因は依然とし て不明であり，本態的治療法も確立されていないものだけに，栄養学的処方によって延命効果を期待するこ とは，本症の療護にとって，今日的に重要な意義をもつものと考えざるを得ない。そして，栄養学的処方の基 
盤になるものがエネルギー所要量の算定で あり， BM はこれの不可欠な構成 要素で あるので, BM のもつ意義は大きい。

我が国で, PMD 患者の BM を測定し た報告は少ない。鈴木2 ${ }^{2)}$ は, 我が国で初め てD型患者の $\mathrm{BM}$ を測定して, PMD患者 の単位体重当たり $\mathrm{BM}$ は基準値と大差を 認めなかったと述べ，松家ら゙)は, PMD 患者の栄養摂取状態を調査する際に合わせ て BM を測定し，約30\%高かったとして いる。そして今回, 著者らの測定では, 平 均約 $11 \%$ 低い結果が得られた。

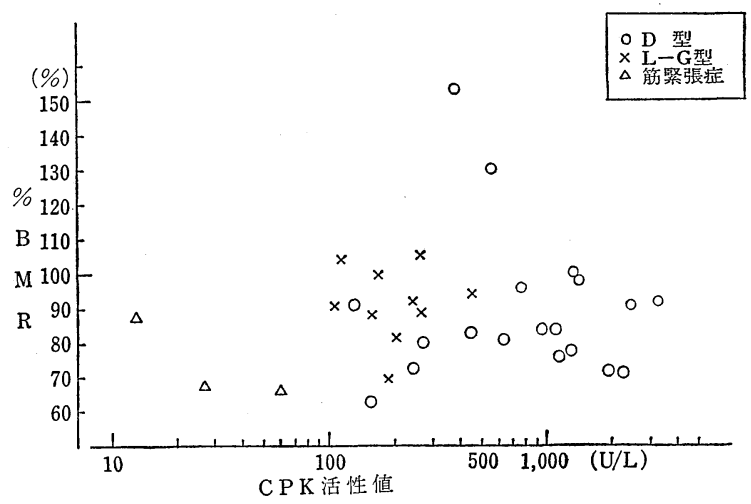

図 8 PMD 患者の血清 $\mathrm{CPK}$ 活性值と\% BMR の関係

それでは,このように 3 者によって3 様 に得られた結果の矛盾は何に原因すると考觉るべきか, といらことであろら。著者らは，これは対象とした PMD 患者集団の, 平均体重偏差值の大小に起因する現象的差異と理解している。このことは前記の鈴木 ${ }^{10)}$, 松家の資料について，体重偏差值と\% BMR を再計算すると，前者のそれは71.6\%と108.6, 後者のそれは $49.5 \%$ と 124.9 となる。また, 著者ら ${ }^{11}$ が15年前に測定した值は, それぞれ $69.9 \%$ と111.5であり, 対象患者 の型別構成や測定時期などが異なりながらも，いずれも今回の対象者 $(89.0 \%, 88.7)$ で得られた前記の回帰 直線, $y=-0.974 x+175.4$ 上にほぼのることが, その理由となっている。

では，PMD 患者の BMR は，本質的には基準值に比べて高，低，同等のいずれと理解すべきであるらか。 この問題については，これまで PMD 患者と標準人との間の体格的プロフィールの差異を等閑に付して論 じてきたことに原因があったと考えざるを得ない。すなわち, 意識下では, 両群の body composition の差を 峻別しながらも, 単位体重当たりや, 体表面積, 単位時間当たりの温発生量にすれば, この差を消去できたと いら錯覚に宿って，基準値と単純に比較していたところに現象を本質と誤認していた原因があるように考えら れるのである。換言すると, 単位体重当たり BM 值で論じる場合に, 対象集団の平均体重の基準体重からの 偏りを考慮せずに結論がなされた点に問題があったと考えられる。

そこで, 著者らは，標準人と同一の体重レベルにある PMD 患者の BMR と基準値との比較を行うべきで あると考光, 前者は後者の78\%に低下することを明らかにした。ゆ壳に, PMD 患者の BMR は健常者に比べ て低下すると考劣るのが本質的認識といらべきであろう。なお，この点に関しては, lean body mass 当たり のBM として比較検討しておく必要があり, さらに今後の研究課題であるともいえる。

BM は, 細胞の構造と機能の象徵的指標である。本疾患の病態は, 生体の重要な産熱器官であり, 体重の 約 $50 \%$ 構成比率をもつ筋肉の進行性変性, 退行性菱縮にあるとされている。事実, PMD 患者の全身のカリ ウム量測定結果では D 型の場合は, 健常者に比べて明らかに低下し, lean body mass としての筋肉量の減

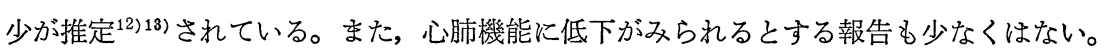

ゆ穴に, PMD 患者の BMR の低下は, 形態的にも機能的にも首肯できることであろう。

以上のことから, 厚生省心身障害研究「進行性筋ジストロフィー症の成因と治療関する研究」において, ＜筋ジストロフィーは筇萎縮による体重減少が著しく, 単位体重当りの基礎代謝量が高いので....... >といら記 
載14)がみられるが，この認識は現象的には一面的な妥当性はあるものの，本質的には誤りであると指摘せざる を得ない。

そして, PMD 患者のるい瘦化現象に注目するあまりに, 全ての PMD 患者の BMR が充進しているかの よらな錯覚に基づいて集団栄養や栄養指導が行われたとすると, 医療過誤を招かないという保障はない。した がって，PMD 患者の栄養確保には個別的対応が不可欠であることを結論的に示していると考劣る。

\section{要 約}

PMD 患者のエネルギー所要量を算定する方法を検討するために，その構成要素としての BM を，対照患 者 20 人を含めた 55 人について測定し，次の結論を得た。

1）一般入院患者の BM は，正常範囲に分布する者が多かったのに比べて，PMD 患者は低下例が53.1\% を占め, 圥進例は6.3\%にすぎず，\% BMR の平均は基準値の $11 \%$ 減となった。

2）これまで PMD 患者の BM は，基準值と同じか，あるいはえ進するとの報告があるが，これは，対象 患者集団の平均体重偏差值の大小による現象的差異にすぎないことを明らかにした。

3）体重偏差值 $(x)$ と\% BMR $(y)$ との相関分析の結果, 両者間には有意の相関が認められ, 前者に対 する後者の回帰直線は $y=-0.974 x+175.4$ が成立した。

4）上記の回帰直線から, 日本人の $\mathrm{BM}$ 基準值に対応する標準人と, 同一体重を有する PMD 患者の BM は，基準值に比べて低下するので，PMD 患者の BM は本質的に低いと理解すべきであろう。

5） $\mathrm{PMD}$ 患者の肥瘦度や Kaup 指数と\% BMR との間には有意の逆相関が認められたが，機能 障害度や 血清 CPK との間には明らかな関係は認められなかった。

以上から，CPK 患者のるい瘦化現象に注目するあまりに, 全ての PMD 患者の BM が充進しているかの ような錯覚に基づいて集団栄着や栄養指導を行うことの危険性を指摘し, 個別的対応が不可欠であることを強 調して結論とする。

本研究は, 昭和58年度, 厚生省神経疾患研究委託費の助成により, 筋ジストロフィー症の療護に関する総合 的研究 (班長 国立療養所, 東埼玉病院 井上満院長) の一端として実施された。

ここに，関係各位に対し，深く感謝申し上げる次第である。

文献

1）厚生省公衆衛生局栄養課: 昭和54年改定 日本人の栄養所要量, p. 36 (1982) 第一出版

2）鈴木泰夫：四国医誌，24，169～170（1968）

3）松家 豊, 新居さつき, 藤原育代, 野町結花, 新山喜昭 : 昭和 57 年度筋ジストロフィー症の療護に関す る総合的研究, 研究成果報告書, pp. 413 416 (1983)

4) Du Bois, E. F. : Basal metabolism in health and disease (1927) Lea \& Febiger, Philadelphia

5) Bondy, P. K. : Duncan's Disease of metabolism (1969) W. B. Saunders, Philadelphia

6) Wohl, M.G. and Goodhart, R.S. : Modern nutrition in health and disease (1960) Lea \& Febiger Philadelphia

7）福山幸夫：筋肉病学／里吉営二郎, 藤倉康夫編, pp. 387 440 (1976) 南江堂

8）三田哲司：内科学而／黒岩義五郎編, pp. 207 227（1978）日本医事新報社 
9）里吉営二郎：日内会誌，67, 1465～1481 (1978)

10）鈴木泰夫：未発表資料，私信

11） 曰谷三郎，荻野幸男，西山邦隆，木村寿栄子：未発表資料（1968）

12) Blahd, W.H., Cassen, B. and Lederen, M. : Ann. New York Acad. Sc., 110, 282 290 (1963)

13）西谷 裕, 森宗 勧, 吉川信嘉, 野口真子, 深瀬政市, 浜本 研, 吉岡三恵子 : 厚生省進行性筋ジス卜 ロフィー症研究班業績集 (II), pp. 80〜84 (1974)

14）木村 恒: 厚生省心身障害研究, 進行性筋ジストロフィ一症の成因と治療関する臨床的研究, p. 293 (1983)

（受付：昭和 59 年 5 月 22 日） 